\title{
Anaerobic Gram Positive Bacteria
}

National Cancer Institute

\section{Source}

National Cancer Institute. Anaerobic Gram Positive Bacteria. NCI Thesaurus. Code C120704.

Any bacteria that does not require oxygen to grow or respirate and has a peptidoglycan rich cell wall that stains dark purple with the Gram staining technique 